\title{
China-US Relations Today: Some Aspects
}

\author{
Duman Zhekenov (Corresponding Author)
}

Nabizhan Mukhametkhanuly

Aliya Akatayeva

Saniya Nurdavletova

Al-Farabi KazNU, Almaty, Al-Farabi 71, 050040, Kazakhstan

Zulfiya Meldibekova

International IT University, Almaty, Manas/Zhandosov 34A/8A, 050035, Kazakhstan

\section{Doi:10.5901/mjss.2015.v6n6s1p360}

\section{Abstract}

\begin{abstract}
The biggest problem which will be discussed in world affairs in the first decade of the 21st Century is the People's Republic of China's fast paced economic growth which has become a key driver of international economic growth. Today the whole world is keeping an eye on China. China's stunning high economic growth and a more active diplomatic relations has attracted not only Asia, Africa, the Pacific region, Latin America and the whole Eurasia. According to some analysts of leading countries American age is coming to its end. According to Albert Keitel (Carnegie foundation) China's Gross Domestic Product nominal will be the same the United States of America by 2020. In 2050 the nominal Gross Domestic Product will become more than twice the size of America. Within 10-15 years America's great economic power certainly will slow down. Here inevitably raises important questions about what developing process will be on an international system? Will China abolish or change the present international system or try to build a new system or be one of the members of the system or become a leading power in the world? Can the US keep its present position? What will happen if the United States and China compete in the same level? What will happen with the new world future under Chinese running if the United States can't keep present position? The answers to these questions are of enormous importance and we will try to find the answers analyzing the United States-China relations at present times.
\end{abstract}

Keywords: People's Republic of China, USA, International relations, New World Order, Foreign policy, Hu Jintao

\section{Introduction}

China will play the main role in running the world economy. The Western world order will be replaced by the new Eastern structural system. China is well positioned as the sole representative from Asia and from the developing world among the permanent members of the United Nations Security Council. Beijing pushes for reforms in international financial institutions that would give China a much more prominent role in setting their policies. China expresses dissatisfaction with US- led management of the global economy.

Soon after taking office President Barack Obama's administration had to make changes in some aspects of their foreign affairs toward eastern and western direction. Former American administration policy toward East has been criticized by China. Last time some American politicians are stating new ideas toward the North-East Asian policy. At the same time, former US national security adviser Z .Brzezinski and G .Kissinger suggested the US - China to take the leading role in global politics by forming "G-2" alignment to deal with salient international problems. Magazine Financial Times of London has published Z. Brzezinski's article where he wrote: "The US and China by forming "G-2" has to develop the situation of the world". According to his words it is already time for China to "Shake the World" and take part in solving strategic problems of the region.

The same ideas were also mentioned by Chinese-American scholars and statesmen. According to them the relationships between the US and China are not only bilateral tie in world politics, steady US-China relations will promote to safeguard world peace and stability. Chinese authors say that they have important common interests; the US with China will run the future global order. In common, Chinese specialists believe that the US-China relations are developing. 
The US should treat China as an emergent global power with its increased economic weight cause the US economic growth is getting slower (Joseph S. Nye Jr, 2010).

\section{The New Steps of the Bilateral Relations}

The US new Barack Obama's administration has made steps to make some changes in the US- China relations and in Asian policy searching for a new way to frame their relationship.

After the world socialist system dismissal the US became sole great power, and is trying to keep its position to rebuild geostrategic global space saving its hegemony. For this purpose the most attention is given to those states with the most important world political, economic and strategic situation. The US still remains the "sole superpower" and is jealousy trying to guard uni-polarity world not only in the region where they are manipulating, but at the same time in Asia- Pacific searching for new impulses for further development.

Washington officials consider that Asia-Pacific region was created under American interest. It goes without saying, that the US has played great role in the Far East during the Cold War. Nevertheless, China is trying to take over the US and not only trying to become its rivalry as well as trying to shake Washington authority. The most important thing for the US is to create economic and strategic base against great China.

Some experts believe that Asia- Pacific region, in the near future will turn to the scene of contest between the US and China. Economic and trade development of the region in the world share is increasing rapidly year by year.50\% of the world trade and 60\% of GDP share belongs to Asia- Pacific region. So, the US is searching for other methods of strengthening its influence on the region. The problem of Taiwan is a real example (Reilly, J., 2012).

Nearly for more than half century the military-political situation in the Far East and Pacific were in the attention of the world. Creation of the US military- political block during the Cold war caused some regional conflicts, especially the Taiwan problem. Since then, Washington is supporting Taiwan and the whole Asia -Pacific region. The US ability to defend Taiwan is the event of an attack by China is increasingly challenged. The US and China have to take account of the problem not to complicate the situation in Asia- Pacific region.

\subsection{A Taiwan issue}

Disputes on Taiwan is the sensitive issue between the US and China. Seeking comprehensive cooperation and partnership with each other will be beneficial for the US-China relation.

After the Second World War, Cairo and Potsdam declarations retuned Taiwan to China. But the contradictions between Europe and socialistic world have supported the US government to provide civil war to Gomindan government and didn't give any chance to unite the island with mainland. In June, 1950 after the Korean War has begun, the President of the US G. Truman stated: "The future of Taiwan will be determined when there is stability in Pacific and peace negotiation with Japan and when UN deals with the problem. After Truman's statement, American government has sent their seventh fleet to Taiwan to prevent it from any kind of aggression. Since that time, the problem of Taiwan has become one of the biggest disputes and contradictions between the US and China.

To improve the US-China relations three communiqués have been singed: The first communiqué (February 28, 1972), known as the Shanghai Communiqué - The United States acknowledges that all Chinese on either side of the Taiwan Strait maintain there is but one China and that Taiwan is a part of China. 2) 1978-. The US had to break its formal diplomatic relations with Taiwan, affirms the ultimate objective of the withdrawal of all U.S. forces and military installations on Taiwan as the tension in the area diminishes. 3) Deng Xiaoping and Jimmy Carter sign the Joint Communiqué on the Establishment of Diplomatic Relations, reestablishing official ties between the two countries.

However, despite Jimmy Carter grants China full diplomatic recognition, Washington soon has declared the new geopolitical game openly. Jimmy Carter has signed "Taiwan Relations Act". The Act stated: "The US has made a step to establish diplomatic relations with China, to solve Taiwan's future fate peacefully. But, any impulse of solving Taiwan problem with the help of other methods will cause great danger to the parts of Pacific region and it will worry the US". In addition to that, "For security of Taiwan people and for the defense against danger of social-economic system of island or to stand against any force, the US will provide Taiwan with defensive arms to enable Taiwan to maintain a sufficient selfdefense capability, but doesn't violate the "One- China policy".

According to the Act, the US obliged to carry out two main tasks in the field of military and defense: first is to provide Taiwan with arms to build up island's defenses; secondly, to stand against force and danger and strengthen the abilities to keep peace and quiet life in island. Today The US is still continuing tradition on selling arms and military technology to Taiwan on the basis of the Act. And also, the Act is exactly giving chance to secure independence and 
develop the abilities of strengthening defense of Taiwan as de- facto. In September 1992, the US made a solution to sell F-16 A/D fighter planes to Taiwan in spite of China's objections. Washington's this action has caused a new intervention to solve Taiwan problem, at the same time it has caused negative connections to build friendly ties between two great powers.

Washington continued its policy to keep distance between the island and the mainland. In September, 1994 the US began to take some measures to develop American- Taiwan relations. If we count, the US has allowed the Minister of Economic and Trade to pay an official visit to Taiwan, and also has changed the department of West American Affairs into Taiwan Economic and Cultural Representatives in America. In addition to that, the US has allowed Taiwan representatives to pay a visit to American government on diplomatic issues. The US supported Taiwan to participate in the works of international organizations. The US- Taiwan way of solving problems together has complicated AmericanChinese relations and strengthen actions of building "Two Chinas" or "One China, One Taiwan" for Taipei government.

In May, 1995 the US allowed the former head of Taiwan Li Danhuei to pay a visit to America. Changing their promises to acknowledge "One China" conception, the government of America maintained Taiwan "two Chinas" or "one China, one Taiwan". In March,1996 the US dispatched two aircraft carrier battle groups to the South-East coast during the military exercises of PRC military power. That has complicated the situation in the Gulf of Taiwan. .

The Chinese side is against of any kind of relations between the US and Taiwan. The representative of Foreign Affairs of PRC Keying Xian has stated that "Taiwan problem is the most sensitive and complex issues in the bilateral US - China relationship."

Beijing considered Taiwan problem as "One or united China" conception defending own independence and territorial integrity. In turn, Beijing's this position worry not only the US, but also Japan and other countries whether China "swallows" the island.

After Chen Shui-bian elected as a president of island in 2000, Washington began to support Taiwanese "pragmatic diplomacy". With the purpose of forming "Two Chinas" or "One China, One Taiwan" and "to acknowledge two sides" was the main strategy to order diplomatic relations with other countries (Kurlantzick, J., 2002).

Taiwan democratization process and the Tiananmen Incident have caused bad impact on American public opinion about China mainland. Several business groups have called PRC's advantageous sides, while others supported the island. In addition to that, the powerful Taiwan lobby in American policy became one of the most important factors in the US.

Clinton administration considered China as one of the most important partners, but his policy was characterized as enemies than allies. Strict policy toward China has been continued under the head of G. Bush. During the presidential election G. Bush has described China as powers produced strategic contest. And then State Secretary Condoleezza Rice in her speech: "China- first of all is not a state trying to hold status - quo, it is the state trying to change balance, and on the contrary it proves China as strategic rival".

\subsection{The new cooperation after September 11, 2001}

American-Chinese relations changed radically following the September 11, 2001 attacks. China strongly supports the US in the war on terrorism, extremism, have worked closely on regional issues. It was good chance for China to act more freely. New relations among three countries Washington- Taipei-Beijing have been established.

From the US side a real step toward dismissing the status- quo were made at the end of 2003. According to Iraq's aggression, Washington officially has called Taiwan to give up from its sovereignty, supporting Beijing. For the US, Chinese trade-economic ties are more important than Taiwan. A Beijing and Washington trade-economic tie covers milliards.

To strengthen strategic position in the Gulf of Taiwan, the US presented Japan- American treaty for establishing security in Taiwan issues. This will develop military- strategic cooperation between the US- Taiwan relations and provide the island with an advanced arms and technology and stand against any aggression and danger (first of all from Chinese side). As a result of this, Taiwan becomes one of the US clients buying military technologies from America. Taiwan is spending milliards of dollars on this purpose.

Washington's double- standard policy has always been criticized by Beijing and they strongly declared, providing Taiwan with new arms do not maintain peace and stability in the Gulf, at the same time, it influences on the US- China relations. According to this, the US must completely stop selling arms to Taiwan.

In 2005 China passed"anti- secession "law. China as de-facto, would prepare to resort to "non- peaceful means", if the authorities of the island tried to separate the island from mainland and declared formal independence (Lomanov, A., 2008, Fewsmith, J., 2008). 
Washington's official representative Condoleezza Rice has sharply criticized China's new anti-secession law, which would cause further conflicts in the region. But the US did not do any actions toward China's policy, to restrict the cooperation in comparison with Taiwan. But the US administration and Pentagon regard China as a competitor, always learning China's growth in economic and military power that plays a greater role in world affairs. American military specialists reassure that China is buying advanced arms from Washington, Russia, France, Germany and today's Chinese military is a professional force that carefully analyzes the American military to identify its weaknesses.

Nevertheless, China will not use military power. According to experts of the Asia- Pacific Center for Security Studies (APCSS) conflicts between great powers toward Taiwan issues are out of the question. All sides have been using military power cause of danger.

In practice China being one of the oldest civilizations has always been willing to take on greater international roles that enhance Chinese national pride and status but do not require costs and risk. From the very beginning Chinese Empire was founded relying on realism and real strategy. Chinese civilization owns psychology of thinking and China is prepared to work in the areas of mutual understanding. 2008 Olympic Games showed the world that China had no intention of joining the island and Taiwan was referred to during the games as "Chinese Taipei," rather than "China's Taipei," as the mainland China government had proposed. Either Chinese Communist Party General Secretary Hu Jintao or new President of China Xi Jinping has declared that they are both seeking a peaceful means of joining the island with the mainland (Jacques, M., 2009, James C. Hsiung, 2009).

In world policy, conflicts among countries based on national interests are considered to be natural phenomenon. Therefore the highest pick of tensions among great powers could be viewed as global wars. The consequences of this scenario are well understood by all the sides involved. Despite the disagreements, they are making all their efforts in order to keep peace and stability in Asia- Pacific region. It is clearly seen from the statements made by state officials of two great powers. The US State Secretary Hillary Clinton has described American- Chinese relationship as "the strategic pivot of the 21st century", American statesman Henry Kissinger has stated that "I have been learning Chinese- American Relations for several ten years and I became aware that cooperation between them was as close as it is right now. Vice chairman of PRC Foreign Ministry Xui Tiakai has stated that "China and the US are being in the same boat, they have done more than any other economy, therefore to find solutions to pull the Asia- Pacific and world economy out of recession.

April 1, 2009 Chairman of PRC Hu Jintao during his meeting with his US colleague said: "Fruitful friendship relations between two countries are not only interests of two countries, it is for the benefit of prosperity of the whole world". According to Hu Jintao after Barack Obama has taken the office, China and the US relations have determined a new way to frame their relations, at the same time they could establish structural system of economic-strategic cooperation. In addition to that Hu Jintao has stated that they would demand adherence to the "one China principle" and would stand against "independent Taiwan" or "two Chinas" principle.

The US President Barack Obama reassured that they would continue relations with Taiwan, in order to improve relations, to uphold peace and stability in the island and they hoped for peaceful settlement. In addition to that, American President declared that the bilateral relations between America and China were not only interests of two countries, the future of whole world directly depended on their relations (Guoxin Xing, 2009).

The effect of relations between the US and China will affect the future world economy. It is time to build a new cooperative relationship between the US and China. Some of the global strategic issues affect all of us. For example, global recession, nuclear proliferation, energetic and climate changes that confront us demand strengthening relations between them.

\section{Discussion}

January 14, 2011 the US State Secretary Hillary Clinton made a statement about American- Chinese relations. She stated that The US and China relationship were facing the most difficult times and they both needed to form habits of cooperation and respect more effectively. Last two years, Barack Obama's administration has established a deep, broad, stable and positive relationship with China. They have made some good results, feeling some success and failure at the same time. If they each meet their responsibilities as great nations, the relationship of two great powers could be strong (Lyle J. Goldstein, 2012).

Several factors affect the US and China strategic rapprochement, the first factor is that they each are dependent on financially. PRC buys most of American Treasure (savings) Bonds.

China officials argue about American large amount of air forces and nuclear submarines, aircraft carries, including strategic arms and military exercises in the Pacific region. American Antimissile Defense System against nuclear 
weapons development in the given region is (in the first place against Chinese nuclear missile force) and all these actions worry China. Military forces intervening in a conflict and preventing China from accomplishing its military objectives. There is not any hope for deviation from these measures of American new administration. Nevertheless Beijing is patient to American military forces against their will.

As for the US, they are concerned about cyber espionage apparently originating from China. American former director of Special Service Center Allen Dallas says: "Last time, we began to talk about red Chinese cyber espionage activities. In the future, Chinese espionage will bring great danger toward Europe. If we give real estimation, today China has become great power in the Asia -Pacific region". And he called colleagues to take measures for these actions immediately (Halper, S., 2010, Glazunov, O.N., 2010).

The same opinion was given by Director of US Reconnaissance Center J. Klepper. "China has full opportunity of becoming rivalry for America. The US military ships are functioning over the South - China Sea, where China is keeping an eye on them. PRC side's actions trying to pull American ships out of the region are full of aggression and danger", he added. In his opinion, America will capture all dangers in twenty years (Inkster, N., 2013).

According to some factors, it is very difficult to believe that the relationship between the US and China or their rivalry never come to its order. It goes without saying that collaboration, cooperation and profitable negotiations between relationships will continue in the process of development, but solving global problems confronting humanity positively, needs much time.

There are contradictions in American actions toward China to some degree. The US in one case is trying to hinder Chinese economy; on the other hand they remember their economic dependence on China. Today PRC is an important trade partner of America. Hindering Chinese economy in some level causes to narrowing their economic spaces. In addition to that, America aims to support Taiwan independence and defend Taiwan from Chinese force in case of uniting Taiwan. As for China, they aim to improve their world authority as well as in the region. They aim to develop their cooperation actively with America, as an important part of their fast modernization. Therefore, they rather try to avoid from complicity bilateral relations.

It is not efficient for US aims, to come to confrontation or to become too close to China. In connection with this, in our opinion, official Washington will take into account the following purposes in cooperation with China:

- $\quad$ In case of breaking WTO rules, the US will impose embargo against Chinese firms and companies, hinder PRC economic growth, to prevent energy resources transportation which exports to China and to send American investors to the region where Chinese companies are working;

- To maintain US superiority in the field of Science and Technology, not to let purchase such projects from the US, from other developed countries(including RF) or not to let these countries purchase or get it with the help of spying, to fight against all means of spying;

- To increase number of services provide by the US Army, in comparison with Chinese National Liberalization Army from the perspectives of not only quantity but quality, to improve the works of military bases in neighborly countries, as well as uniting forces in East Asian regions, to take countermeasures against developing military power;

- They will officially constantly inform that they are always ready to support Taiwan with military aid in any situation, to elongate the determination of the national status of Taiwan.

Under such circumstances, "to provide regional security" American military forces always should be based in the region. In that case, America has the opportunity to control the situation in the region. In addition to that, by adapting bilateral and multilateral relations and cooperation to its interest, the US aims to influence the world situation from the point of their interest. Base of US military forces in the region of East Asia will become one of the important parts of American regional policy. As a result, America will defend their interest in the region by allocating American capitals in a great amount and maintaining security.

With the help of its military authority and the support of its allies, the US is controlling the world economically politically and militarily. It influence on all strategic regions of world. All these priorities are being used as a means of security.

In one of directions of the address to the people of the RK, the President of the Republic of Kazakhstan N. Nazarbayev highlighted the importance of building a nuclear weapon-free world. All new types of nuclear weapons, which are used by America in the name of security and stability, on the contrary, causes to the end of the world. All leading statesmen, leading politicians fully agree with this opinion and the given proposal of the President of the RK is supported by the whole world. Nevertheless, in April of 2011 new nuclear strategy was published in America. It was underlined that nuclear arsenal will remain one of the main ways to preserve security as one of the important means. Despite creating new types of weapons as a means of security the US cannot fully refuse from weapons (it is true not only about the US 
,but also about other countries which have weapons), on the contrary new types of nuclear weapons are being created in order to realize definite tasks.

In connection with the fact that we have the global situation as it is now (China might have acted differently be it another case) China is continuing to improve military technologies with the help of its powerful economy. America is constantly reminding the world community that China is becoming a threat number one for the USA. Documents provided by the White House have stated that China is maintaining a close strategic tie with Asian countries.

Military contest between two powers have negatively influenced on the relations between China and the USA. As a result of the meeting of B.Obama and Hu Jintao in April of 2009, in London two sides have signed an agreement on American-Chinese strategic and economic ties. These agreements include issues concerning the improvement of cooperation of military departments of the USA and China and the problem of the world crisis (Davydov, A.S., 2011).

During the American administrative negotiations it promised to cut down its financial deficiency by two times after it improves its economic situation. In its turn China promised to widen the sphere of internal demand and strengthen macrocontrols. After the London meeting many American, Chinese as well as world politicians started discussing new forms of partnership and alliance.

America was watching how, after the second decade of the XXI century China has changed its concept of the 'peaceful civilization' to 'harmonious world'. It was accepted by the American community as a strive for economic partnership during the world crisis. After B.Obama's visit to China Chinese government that was supporting the harmonious world direction agreed to improve military cooperation. Military cooperation between two countries has halted after the visit of Bush junior to Taiwan.

After the meeting of leaders in London, many articles which were published were about "G-2. In 18 of November 2009 there was a meeting between the US President and Chinese vice president Ban Xebio in Beijing. During the meeting Ban Xebio has announced that China was against "G-2". He stressed; "China is still developing country and its population is more than one and half milliard. In order to get the Modernized Country position China has to go long way. China will lead its own peaceful foreign policy and China has no intention of becoming ally with any country. The global problems should be solved not only by one or two countries' advice, but it must be solved by the participation of the whole countries" (Dobbins, J., 2012).

Cooperation between two countries has halted in 2010. Contradictions among American Google company; American obligation to provide Taiwan with arms; as a result, official China cut the military cooperation with Washington; Dalai Lama's official visit to America; China's human rights record, and US criticism of it, have long been major sources of friction in the US-China relationship; Cyber espionage apparently originating from China is a growing issue in the U.S.China relationship; China has declined to impose its own bilateral sanctions and has criticized other countries for doing so; the sanction against Chinese business; the crisis in Korean peninsula; quarrels about Liu Xiaobo, a political dissident, writer and 2010 Nobel Peace Prize winner, all these scenes are halts of American and Chinese relations.

Despite the contradictions and conflicts relations between two countries, mutual distrust has escalated last years in the sphere of trade- economic, scientific- technology and cultural relations. They blame each other for growing tensions. Only economically dependence, China's economic weight, strategic intentions, and military capabilities will increasingly impact on US policy choices. Chinese holds US debt. China holds the US Treasury securities (about more than $\$ 900$ milliard) according to some facts- $\$ 1$ trillion), these resources are funding American low balance of payments (Savinski S.P. 2010, Etzioni, A., 2013).

The chief scientific worker of Russian Far East Scientific Academy Yaakov Berger gave his own opinion in his article: "China GDP nominal became the world's second largest economy and is close to the largest economy. If China continues its trends, they will overtake America not only in the sphere of economy as well as in the other spheres. American economy has slowed and the growth of unemployment has increased. These PRC trends aim to become the first great power. The US should welcome China; even they do not like the scenario (Yakov, B., 2012).

China is the major creditor nation and largest foreign holder of America. Last time has been crediting more than Word International Bank. And China is opening regional markets for their own goods. In this case is strengthening its influence on Europe. Today China has become "the heart" of world economy and is continuously working is of importance. China has appealed for the safeguarding of Chinese investments in US treasuries and called for policies that maintain the purchasing value of the Dollar. In conclusion, each sides are interested in warming algidity which was formed between two countries in 2010 (Bolutko, A.V., 2011, Kuznetsov, I., 2010).

Nevertheless Heads of China have agreed to ease the case of coming American companies to China and to give rivalry in the same level. The US in its turn agreed not to prevent China from exporting advanced technology products to the region. B. Obama has stated: "Chinese economic growth gives great opportunities to increase work places. We are ready to provide you with planes, cars and with computer programs". 
In addition to economic issues, which have been discussed by leaders were Korean peninsula situation, sanctions against Iran nuclear program cooperation, as well the North Sudan referendum issue. The US President has tried to develop the theme on human rights. Hu Jintao has agreed that he was ready to have a talk on the issue, but he has warned to keep the strategy not to interfere in home affairs. Hu Jintao has admitted that they had to work out the issue of human rights.

In the XXI century China has become to play a vital role in international relations strongly influencing on international order. Economic growth, through which PRC took one of the leading place amongst top 10 most powerful countries, has taken permanent effect in long and short term prognosis. But China's GDP refers mostly to the country itself, at the same time GDP per capita is still relatively on a very low level about 6100 USD, that in comparison with, for example USA's GDP 8th time lesser (Brown, K., 2012, Yong Deng, 2014). Thus being one of the leading country in the World, China has a huge gaps in the domestic welfare, it means that quality of live in PRC still needs to be improved.

Geopolitically China's interests lie mostly in the region of Asia Pacific, prospective international markets of the South-East Asia are very interested in China's financial investments. But USA in its turn has a very strong position in the region, strategic alliances with Philippines, Australia, South Korea, Thailand, Japan provides sustain military presence. Generally bilateral relations between China and USA can be described as "reserved opposition". Neither of these two countries don't want to push forward existent issues such as Taiwan independence, of military rivalry in the regions. USA administration understands the importance of China's economy and potential in the region, the same about China's leaders. Both countries primarily interested in creating mutual profitable approach especially to the questions of trade and economy. Moreover, being the biggest creditor of USA, China directly dependent on fluctuations of world trade and market and USA has all tools to influence and interfere to these processes that are vital to PRC's economical growth.

\section{Conclusion}

Development of U.S.- China relations at the present stage allows some conclusions: Firstly, the change in the relationship is mainly due to the political independence of China and its rapid economic development, improved status in the international arena and to strengthen strategic role in the relations between the two countries. Second, bilateral friendly cooperation and common development not only provide benefits to the peoples of China and the U.S., but also conducive to stability, peace and flourishing in the Asia-Pacific region and the world. Thirdly, from the settlement of the Taiwan issue in accordance with the three communiqués directly dependent stability, improvement and development of China-US relations. Fourthly, we should resolve differences in a spirit of mutual respect and equal negotiation and commitment to a common, despite the existing differences.

Despite the political challenges, China and the United States are interested in developing trade and economic relations, which is beneficial to the two peoples and contributes to stable development of bilateral relations.

In 2012, in China the authority of $\mathrm{Hu}$ Jintao was replaced by Xi Jinping. B. Obama will be replace after the election in 2016. First of all, all contradictions and new issues, PRC and the US internal developments depend on new leaders' actions. Nevertheless, the world relations and the future of humanity depend on the relations of these two countries; living in peaceful Kazakhstan we wish the countries to have good relations with each other.

\section{References}

Bolutko, A.V. (2011)Relations between PRC - USA: Critical periodlIChina in the global and regional policy. History and modernity. Issue XVI. From ed.Sovranova E.I. M., Institute of the Far East - Russian Academy of Science,.

Brown, K., (2012)Hu Jintao - China's silent ruler Chatham house, U,.

Davydov, A.S. (2011) Chinese - American relations in 2009-2011 yy. IIPeople's Republic of China: policy, economy, cultures 2010-2011 yy. From ed. M.L. Titarenko. M., Institute of the Far East - Russian Academy of Sciences,.

Dobbins, J., (2012) War with China// Survival: Global Politics and Strategy Volume 54, Issue 4, pages 7-2.

Etzioni, A., (2013) Accommodating China// Survival: Global Politics and Strategy, Volume 55, Issue 2, pages 45-60.

Fewsmith, J., (2008) China since Tiananmen, second edition, Cambridge University press.

Glazunov, O.N. (2010) Chinese danger treatment.

Guoxin Xing, (2009) Hu Jintao's Political Thinking and Legitimacy Building: A Post-Marxist Perspective/l Asian Affairs: An American Review, Volume 36, Issue 4, pages 213-226.

Halper, S., (2010) The Beijing Consensus, basic books, New York and London.

Inkster, N., (2013) Conflict Foretold: America and China// Survival: Global Politics and Strategy, Volume 55, Issue 5, pages 7-28

Jacques, M., (2009) When China rules the world: The rise of the Middle Kingdom and the End of the Western World, Allen Lane, London. 
James C. Hsiung, (2009) From Revolutionary Regime to Normal Governance: China's Long March toward Political Reform/l Asian Affairs: An American Review, Volume 36, Issue 1, pages 29-46.

Joseph S. Nye Jr., (2010) American and Chinese Power after the Financial Crisis// The Washington Quarterly , Volume 33, Issue 4, pages 143-153.

Kurlantzick, J., (2002) China: Economic power, political enigma// The Washington Quarterly, Volume 25, Issue 3, pages 59-67.

Kuznetsov, I. (2010) «Global convergence» in the context of U.S.A foreign policy strategy. International Life, №4.

Lomanov, A. (2008) Multipolar hegemony. //Global policy in Russia. Thom 6, №5.

Lyle J. Goldstein (2012) Resetting the US-China Security Relationship// Survival: Global Politics and Strategy Volume 53, Issue 2, pages 89-116.

Reilly, J., (2012) China's Unilateral Sanctions// The Washington Quarterly, Volume 35, Issue 4, pages 121-133.

Savinski S.P. (2010) China and economical crisis in USA. I/Economy PRC: measures to overcome the affects of the global crisis.

Yakov, B., (2012) China: course of cautious reforms http://www.ng.ru/courier/2012-10-15/10_china.html.

Yong Deng, (2014) China: The Post-Responsible Power// The Washington Quarterly, Volume 37, Issue 4, pages 117-132. 